\title{
INTERNATIONAL MIGRATION, INCOME TAXES AND TRANSFERS: A WELFARE ANALYSIS
}

\author{
MiCHAEL S. MiCHAEL \\ CESIFo WORKING PAPER No. 780 \\ CATEGORY 4: LABOUR MARKETS \\ SEPTEMBER 2002
}
An electronic version of the paper may be downloaded - from the SSRN website: www.SSRN.com
- from the CESifo website: www.CESifo.de




\title{
INTERNATIONAL MIGRATION, INCOME TAXES AND TRANSFERS: A WELFARE ANALYSIS
}

\begin{abstract}
An important issue in public policy debates is the effect of international migration on welfare in source and host countries. We address this issue by constructing a general equilibrium model of a two-class source or host country. Each country produces many traded and non-traded goods, uses income taxes and distributes the tax receipts equally to all individuals. The analysis examines the effects of permanent migration on class, and national welfare. We show, among other things, that marginal immigration hurts people already in the country regardless of whether or not non-traded goods exist. The presence of international capital mobility, however, may reverse the above result.
\end{abstract}

JEL Classification: F22.

Keywords: international migration, taxes, transfers, welfare.

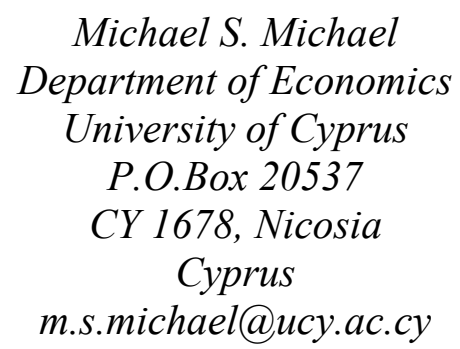

I acknowledge the useful comments and suggestions by Panos Hatzipanayotou, and Costas Hadjiyiannis. 


\section{International Migration, Income Taxes and Transfers: A Welfare Analysis}

\section{Introduction}

In the absence of income taxes, transfers and public goods, the literature on international migration, when emigrants possess only labor, has established that (i) finite permanent migration is beneficial for the nationals in the destination country and detrimental for people left behind in the source country, and (ii) marginal permanent migration has no welfare effects in either country (e.g., Berry and Soligo 1969). Wong (1985) and Quibria (1988) extend these results to the case with many goods and factors and to the case where goods prices are endogenously determined or exogenously fixed. In an economy with traded and non-traded goods, Rivera-Batiz (1982) showed that the level of welfare of remaining residents falls as a result of emigration or at best remains the same. The latter possibility emerges when both emigrants and non-emigrants have identical endowments of productive factors. Djajic (1998), in a model with traded and non-traded goods shows that in the presence of foreign capital, the previous welfare effects may be reversed.

While the international migration theory predicts that in most cases immigration benefits the residents in the host country, in reality, we observed that most developed countries oppose free immigration. Some argue that this opposition is not only due to the effects of immigration on the local labor market, but also due to the fiscal effects of immigration. That is, the fiscal burdens to host economies due to immigration. Specifically, in modern economies, governments impose income taxes and implement programs, which transfer income in cash or in kind e.g., health, education. It is subsequently maintained that immigrant contributions, through taxes, to sustain such programs fall short of the benefits immigrants enjoy from their provision. In advanced countries, the government expenditure as a percentage of GDP amounts between 30 to 50 percent.

The fact that in modern economies, governments impose income taxes, make income transfers and provide public goods has only recently been introduced explicitly in the welfare analysis of international migration. Wildasin (1994) using a single good model with income taxes and transfers shows, among other things, that free immigration may lead to pareto-inferior outcomes if in the no-immigration situation, owners of the immobile factor are being taxed to provide transfer payments to mobile workers. Wellisch and Wildasin (1996), assuming that prices of goods are 
fixed, examine within a system of jurisdictions the effect of immigration in one jurisdiction. They show, among other things, that when each jurisdiction chooses optimal redistribution policies, the external effects are purely fiscal, that is, immigrants who make net fiscal payments (receipts) create external benefits (costs). Wellisch and Walz (1998) show that social welfare in countries with relatively small number of low-skilled native workers is higher with free trade than with free migration due to redistribution of income towards immigrating workers.

The purpose of this analysis is to examine some of the previous questions and related ones using a model with quite general assumptions regarding the structure of the economy. To this end, we build a general equilibrium model of a small open country where we allowed the existence of non-traded goods, international capital mobility and two classes of individuals. The capitalists who possess labor, capital and other factors of production, and the workers, who possess only labor. Migrants are from the group of workers. The government imposes income taxes and makes income transfers. Within this framework, we examine the effects of an exogenous migration in the host country's social and group welfare, with and without non-traded goods and international capital mobility. While most previous studies focus on the welfare effects of immigration on host countries, the present framework is quite general and enables us to reach conclusions for host and source countries alike. ${ }^{1}$ We show, among other things, that in the absence of international capital mobility, marginal immigration hurts individuals already in the country regardless of whether or not nontraded goods exist. In the presence of international capital mobility, however, the above result could be reversed.

\section{The Model}

Consider an open economy producing a number of traded goods using labor, L, capital, K, and other factors of production (e.g., land). It is assumed that the number of factors exceeds the number of goods and thus changes in factor supplies affect factor rewards. Commodity trade is free so that domestic and world goods prices are equal. Capital is perfectly mobile in international capital markets. The economy is small in world capital and goods markets. Thus changes in domestic

\footnotetext{
${ }^{1}$ For example, the only study that allows prices of goods to vary is that by Wellisch and Walz (1998). They assume, however, identical homothetic utility functions for all individuals and identical production functions in the two countries.
} 
policies do not affect the world prices of goods and the world net rate of return to capital, $\mathrm{r}^{*}$.

Domestic endowments of factors of production are fixed, but the domestic supply of capital is variable due to international mobility and that of labor is variable due to international migration. We assume full employment. Production technologies are strictly concave in capital and labor.

Let $\mathrm{R}(\mathbf{p}, \mathrm{K}, \mathrm{L})$ denote the maximum value of the private gross domestic product (GDP) given the vector of traded goods prices, $\mathbf{p}$, the domestic supply of capital, K, and labor L. The domestic supply of capital equals the domestic endowments $\bar{K}$ plus the foreign capital located at home when the country is a net capital importer, and minus the domestic capital located abroad in the case where the country is a net capital exporter. The fixed endowments of the immobile factors and the fixed prices of the traded goods are omitted from the GDP function since they do not affect the analysis. The partial derivatives of the GDP function with respect to L, and $\mathrm{K}$ (i.e., $\mathrm{R}_{\mathrm{L}}, \mathrm{R}_{\mathrm{k}}$ ) give the marginal revenue product of labor and capital respectively. Henceforth, all subscripts denote partial derivatives. The $R(K, L)$ function is assumed to be strictly concave in $\mathrm{L}$ and $\mathrm{K}$ (i.e., $\mathrm{R}_{\mathrm{LL}}$ and $\mathrm{R}_{\mathrm{KK}}$ are negative). In equilibrium, the domestic rate of return to labor equals the factor's marginal revenue product (i.e., $\mathrm{R}_{\mathrm{L}}$ ) in the alternative domestic uses.

We consider an economy comprising of two classes of identical individuals, capitalists (k) and workers (w). A representative capitalist possesses a unit of labor, and other factors of production, while a representative worker possesses only a unit of labor. It is assumed that capitalists do not migrate. Thus migrants are from the class of workers. The expenditure function for a representative individual in class $j(j=k, w)$ is denoted by $\mathrm{e}^{\mathrm{j}}\left(\mathbf{p}, \mathrm{u}^{\mathrm{j}}\right)$, and shows the minimum expenditure required by that person to achieve the utility level $\mathrm{u}^{\mathrm{j}}$. Since the prices of traded good are fixed, they are omitted from the expenditure functions. It is assumed that migration is permanent in the sense that immigrants do not remit any of their income earnings in the host country to the source country. ${ }^{2}$

\footnotetext{
${ }^{2}$ Note that in the present analysis with international mobility of labor and capital, we reserve the terms "source" and "host" countries for labor migration.
} 
The country imposes income taxes and redistributes the tax revenue equally to all residents. ${ }^{3}$ The country's income expenditure identity requires that expenditure by all capitalists and workers must equal the total net income from production plus transfer payments minus the net payments to foreign capital. That is

$$
\mathrm{L}^{\mathrm{k}} \mathrm{e}^{\mathrm{k}}\left(\mathrm{u}^{\mathrm{k}}\right)+\mathrm{L}^{\mathrm{w}} \mathrm{e}^{\mathrm{w}}\left(\mathrm{u}^{\mathrm{w}}\right)=\mathrm{R}(\mathrm{L}, \mathrm{K})-\mathrm{r}^{*} \mathrm{~K}^{\mathrm{f}}
$$

where $\mathrm{K}^{\mathrm{f}}$ is positive when the home country is a net importer of foreign capital and negative when it is a net exporter of capital, and $\mathrm{r}^{*}$ is the world net rate of return to capital. Note that $\mathrm{dK}=\mathrm{dK}^{\mathrm{f}}$. Since capital is perfectly mobile internationally, equilibrium in the capital market requires that the domestic and world net rates of return to capital are equal. That is,

$$
r^{*}=\left(1-\rho_{k}\right) R_{K}(K, L),
$$

where $\rho_{\mathrm{k}}$ is the linear income tax rate on non-wage income (i.e., income from capital and other factors of production).

The income expenditure identity for a representative worker requires that his expenditure equal his net income from work (i.e., net wage) plus the transfer payments from the government. The transfer payment that a representative worker receives equals total tax revenue divided by the total number of people in the country. Thus, the income expenditure identity for the class of workers is given by

$$
\mathrm{L}^{\mathrm{w}} \mathrm{e}^{\mathrm{w}}\left(\mathrm{u}^{\mathrm{w}}\right)=\left(1-\rho_{\mathrm{L}}\right) \mathrm{L}^{\mathrm{w}} \mathrm{R}_{\mathrm{L}}(\mathrm{L}, \mathrm{K})+\mathrm{L}^{\mathrm{w}}\left(\rho_{\mathrm{L}} \mathrm{LR}_{\mathrm{L}}+\rho_{\mathrm{k}}\left(\mathrm{R}-\mathrm{LR}_{\mathrm{L}}\right)\right) / \mathrm{L}
$$

where $\mathrm{L}=\mathrm{L}^{\mathrm{k}}+\mathrm{L}^{\mathrm{w}}$, and $\rho_{\mathrm{L}}$ is the linear income tax rate on wage income. ${ }^{4}$ A worker has an incentive to migrate if the total income earned in the host country (i.e., net income from work and fiscal benefits) is greater than income earned in the source country.

\footnotetext{
${ }^{3}$ This transfer payment to each individual is basically the fiscal benefit per individual, which can take the form of provision by the government rival (congestable) public services such as health care, education etc. We assume that the country treats all individuals equally, regardless of their origin. For an extensive discussion of this issue, see for example Wellisch and Wildasin (1996).

${ }^{4}$ See Razin and Sadka (1995) for the use of a linear income tax rate in a similar analysis.
} 


\section{The Welfare Effects of Migration with Capital Mobility}

\subsection{Migration and social welfare}

The social welfare function is defined as the sum of the utilities of all persons with equal weights and with constant number of individuals. ${ }^{5}$ Total differentiation of (1) and (2), and noting $\mathrm{r}^{*}$ is constant gives the social welfare effect of migration as follows: ${ }^{6}$

$$
(d W / d L)=-\lambda-\rho_{k} R_{K} R_{K K}^{-1} R_{K L}
$$

where using equation (3), $\lambda \quad=\mathrm{e}^{\mathrm{w}}-\mathrm{R}_{\mathrm{L}}=\rho_{\mathrm{k}}\left(\mathrm{R}-\mathrm{L} \mathrm{R}_{\mathrm{L}}\right) / \mathrm{L}$ and is positive, $d W=L^{k} e_{u}^{k} d u^{k}+L^{w} e_{u}^{w} d u^{w}$ and $\mathrm{dL}=\mathrm{dL}^{\mathrm{w}}$. The $\mathrm{dW}$ is the weighted sum of changes in the utility of all the initial residents in the host country. Thus we call $\mathrm{dW}$ the change in social welfare. The variable $\lambda$ represents the tax receipts from taxing the income of fixed factors and capital located at home, per individual located in the country. That is, $\lambda$ are the tax receipts from taxing the non-wage income in the country per individual. The other term in equation (4) (i.e., $\left.-\rho_{k} R_{K} R_{K K}^{-1} R_{K L}=\rho_{k} R_{K}(d K / d L)\right)$ shows how the tax revenue from taxing the return to capital is affected when migration occurs.

In the absence of international capital mobility (i.e., $\mathrm{dK}=\mathrm{K}^{\mathrm{f}}=0$ ) equation (2) does not hold and equations (1) and (3) are replaced by

$$
\begin{aligned}
& \mathrm{L}^{\mathrm{k}} \mathrm{e}^{\mathrm{k}}\left(\mathrm{u}^{\mathrm{k}}\right)+\mathrm{L}^{\mathrm{w}} \mathrm{e}^{\mathrm{w}}\left(\mathrm{u}^{\mathrm{w}}\right)=\mathrm{R}(\mathrm{L}), \\
& \mathrm{L}^{\mathrm{w}} \mathrm{e}^{\mathrm{w}}\left(\mathrm{u}^{\mathrm{w}}\right)=\left(1-\rho_{\mathrm{L}}\right) \mathrm{L}^{\mathrm{w}} \mathrm{R}_{\mathrm{L}}(\mathrm{L})+\mathrm{L}^{\mathrm{w}}\left(\rho_{\mathrm{L}} \mathrm{LR}_{\mathrm{L}}+\rho_{\mathrm{k}}\left(\mathrm{R}-\mathrm{LR}_{\mathrm{L}}\right)\right) / \mathrm{L} .
\end{aligned}
$$

Differentiating equation $\left(1^{\prime}\right)$ and using equation $\left(3^{\prime}\right)$, we get $(\mathrm{dW} / \mathrm{dL})=-\lambda$. In this case, it becomes very clear that immigration (i.e., $\mathrm{dL}>0$ ) reduces the social welfare of the host country. That is, the combined welfare of those workers and capitalists

5 This type of social welfare function has been widely used in migration economics. It is evident that different types of social welfare function will provide different, even opposite results.

${ }^{6}$ We assume that only a small number of people are allowed to migrate, and this is usually the practice amongst most host countries. This immigration flow usually is not large enough to equalize net income of workers in the host and source countries. 
already in the host country decreases. The intuition is very simple. Since the immigrant possesses only labor, his income is less than the average income of those already in the country, and thus, he is a net fiscal beneficiary. That is, his receipts from the host government exceed his payments by the amount $\lambda$, at the expense of the total welfare of those already in the host country.

When capital is internationally mobile, the social welfare effects of migration could be reversed. We assume and maintain for the rest of the analysis that labor and capital are complements in production (i.e., $\mathrm{R}_{\mathrm{LK}}$ is positive). This is usually the case. Then, the second term in equation (4) is of the opposite sign from the first term. In this case, immigration may increase the welfare of those already in the country when capital and labor are complements. That is, when a worker comes in the country, the marginal revenue product of capital increases causing capital inflow, and thus capital income and tax receipt increase. This increase in tax receipts could outweigh the cost due to the fact that the immigrant is a net fiscal beneficiary, in which case the combined welfare of capitalists and workers already in the host country rises. ${ }^{7}$

Proposition 1. In the presence of income taxes and transfers and no international capital mobility, marginal immigration hurts those already in the host country. When, however, capital is internationally mobile the above result is weaker and it could be reversed.

\subsection{Migration and the welfare of the non-immigrating workers}

Differentiating equation (2) and (3), we get the effect of migration on the welfare of non-migrating workers as follows:

$$
\begin{aligned}
L^{w} e_{u}^{w}\left(d u^{w} / d L\right) & =-\mu\left(\lambda+\rho_{k} R_{K} R_{K K}^{-1} R_{K L}\right)+\left(1-\rho_{k}\right) L^{w}\left(R_{L L}-R_{L K} R_{K K}^{-1} R_{K L}\right) \\
& =\mu(d W / d L)+\left(1-\rho_{k}\right) L^{w}\left(R_{L L}-R_{L k} R_{K K}^{-1} R_{K L}\right),
\end{aligned}
$$

where $\mu=\left(\mathrm{L}^{\mathrm{w}} / \mathrm{L}\right)$ is the percentage of workers in the total population.

In the absence of international capital mobility (i.e., $\mathrm{K}^{\mathrm{f}}=\mathrm{dK}=0$ ) equation (2) does not hold. Differentiating equation ( $\left.3^{\prime}\right)$, the effect of immigration on the welfare

Note that when the tax rate on the internationally mobile capital is zero, we get the same results whether or not capital is internationally mobile. 
of workers already in the country is given by $L^{w} e_{u}^{w}\left(d u^{w} / d L\right)=-\mu \lambda+\left(1-\rho_{k}\right) L^{w} R_{L L}$. In this case, immigration entails two effects on the welfare of workers already residing in the host country. The first effect (i.e., $\mu \lambda$ ), which we call the net fiscal effect, and the second effect (i.e., $\left.\left(1-\rho_{k}\right) L^{w} R_{L L}\right)$, which we call the wage effect. In this case, immigration decreases the welfare of the workers already in the host country, not only because the immigrating workers are net fiscal beneficiaries and thus less is left for the workers already residing there, but also because immigration decreases the marginal revenue product of labor and thus it decreases their wages.

When, however, capital is internationally mobile, the welfare effects are not so clear. The term in the first parenthesis on the right hand side of equation (5) is the same as the right hand side of equation (4) and has an ambiguous sign. The term in the second parenthesis on the right hand side (i.e., $\left(R_{L L}-R_{L K} R_{K K}^{-1} R_{K L}\right)$ ), captures the effect of migration on wages directly, and indirectly, through the induced capital mobility, and is negative since it is assumed that the GDP function is strictly concave in factor supplies. Thus, in this case, the sufficient but not necessary condition for the welfare of the workers already in the country to decrease with immigration is that all people already in the country (workers and capitalists combined) are hurt from immigration, that is, the social welfare effect is negative.

Comparing the welfare effect of international immigration on workers when capital is internationally mobile to when it is not, assuming everything else is the same, we observe smaller losses to workers already in the host country in the former rather than in the latter case and we may even observe a reversal of the effect. That is, a possible welfare improvement for the workers already residing in the country.

Proposition 2. In the presence of income taxes and transfers and no international capital mobility, marginal immigration decreases the welfare of workers already in the country. The presence of internationally mobile capital decreases the welfare losses of marginal immigration on workers already in the country, and it may reverse the effects. ${ }^{8}$

8 Observing equation (5), we similarly can state that in the absence of international capital mobility, international marginal emigration increases the welfare of the initial group of workers in the source country. The presence of international capital mobility decreases the benefits of marginal emigration on the initial group of workers in the source country and it may reverse the effect. 


\subsection{Migration and the welfare of capitalists.}

Differentiating equation (1) and (2) and using equation (3), or subtracting equation (5) from (4), gives the effect of migration on the welfare of capitalists as follows:

$$
L^{k} e_{u}^{k}\left(d u^{k} / d L\right)=-(1-\mu)\left(\lambda+\rho_{k} R_{K} R_{K K}^{-1} R_{K L}\right)-\left(1-\rho_{k}\right) L^{w}\left(R_{L L}-R_{L K} R_{K K}^{-1} R_{K L}\right)
$$

In the absence of international capital mobility, differentiating equation (1') and using (3'), the effect of migration on the welfare of capitalists is given by $L^{k}\left(d u^{k} / d L\right)=-(1-\mu) \lambda-\left(1-\rho_{k}\right) L^{w} R_{L L}$. Thus, in this case immigration through the net fiscal effect affects negatively the welfare of capitalists in the host country, while the impact through the wage effect, is positive. The total effect is ambiguous.

Equation (6) shows the effect of migration on the welfare of capitalists in the case where capital is internationally mobile. The first term on the right hand side of equation (6) is the net fiscal effect of immigration, and will affect negatively the welfare of capitalists if the social welfare effect of immigration is negative (i.e., $\mathrm{dW} / \mathrm{dL})<0$ ). The second right hand side term is the effect of migration on wages directly, and indirectly, through the induced capital mobility. Thus immigration through the wage effect affects positively the welfare of capitalists in the host country, while the net fiscal effect of immigration is ambiguous, resulting to an ambiguous total effect. Thus, if immigration increases (decreases) social welfare in the host country, then immigration has a positive (ambiguous) effect on the welfare of the host country's capitalists.

The presence of international capital mobility has no clear effects on the welfare of capitalists. On the one hand, it reduces the negative effects of immigration on wages, affecting negatively the welfare of capitalists in the host country. On the other hand, it increases the net fiscal benefits to capitalists due to immigration.

\section{Migration and Welfare in the Presence of Non-Traded Goods}

\subsection{Migration and social welfare}

Consider now the case where along with many traded goods, a number of nontraded goods are produced. The prices of the non-traded goods are endogenously 
determined in their respective domestic markets. Migration induced changes in the prices of non-traded goods may reverse the welfare effects of migration. For simplicity, we now assume that capital is internationally immobile (i.e., $\mathrm{dK}=\mathrm{K}^{\mathrm{f}}=0$ and equation (2) does not hold). All the other assumptions of the model remain the same. In the expenditure and GDP functions the price vector of the non-traded goods is included, while the GDP function now does not include K. The country's income expenditure identity in this case can be written as follows:

$$
\mathrm{L}^{\mathrm{k}} \mathrm{e}^{\mathrm{k}}\left(\mathrm{u}^{\mathrm{k}}, \mathbf{q}\right)+\mathrm{L}^{\mathrm{w}} \mathrm{e}^{\mathrm{w}}\left(\mathrm{u}^{\mathrm{w}}, \mathbf{q}\right)=\mathrm{R}(\mathbf{q}, \mathrm{L})
$$

where $\mathbf{q}$ is the price vector of the non-traded goods. The equilibrium in the $i^{\text {th }}$ nontraded good market is achieved with the equality of demand and supply of the $i^{\text {th }}$ nontraded good. That is,

$$
L^{k} e_{q_{i}}^{k}\left(u^{k}, q\right)+L^{w} e_{q_{i}}^{w}\left(u^{w}, q\right)-R_{q_{i}}(q, L)=0,
$$

where $e_{q_{i}}^{j}$ is the compensated demand for the $i^{\text {th }}$ non-traded good by an individual in group j.

Differentiating (7) and using (8), we get that $(\mathrm{dW} / \mathrm{dL})=-\lambda$. That is, the social welfare effect of migration is independent of the induced changes in the non-traded goods prices.

Proposition 3. In the presence of income taxes and transfers, and in the absence of international capital mobility, marginal immigration hurts those already in the host country whether or not non-traded goods exist in the economy.

Examining separately the effect of migration on the welfare of workers and capitalists better captures the intuition of this result.

\subsection{Welfare effects on workers and capitalists}

While total social welfare is not affected by changes in the prices of non-traded goods when capital is internationally immobile, the welfare of the two groups of 
people is affected by such changes. ${ }^{9}$ In the presence of a nontraded good equation ( $\left.3^{\prime}\right)$ is replaced by

$$
\mathrm{L}^{\mathrm{w}} \mathrm{e}^{\mathrm{w}}\left(\mathrm{q}, \mathrm{u}^{\mathrm{w}}\right)=\left(1-\rho_{\mathrm{L}}\right) \mathrm{L}^{\mathrm{w}} \mathrm{R}_{\mathrm{L}}(\mathrm{q}, \mathrm{L})+\mathrm{L}^{\mathrm{w}}\left(\rho_{\mathrm{L}} \mathrm{LR}_{\mathrm{L}}+\rho_{\mathrm{k}}\left(\mathrm{R}-\mathrm{LR}_{\mathrm{L}}\right)\right) / \mathrm{L}
$$

Differentiating equation (3") and (7) and using (3") and (8) gives for this case the effect of migration on workers and capitalists welfare as follows:

$$
\begin{aligned}
& L^{w} e_{u}^{w} d u^{w} / d L=\Omega(d q / d L)-\mu \lambda+\left(1-\rho_{k}\right) L^{w} R_{L L}, \\
& L^{k} e_{u}^{k} d u^{k} / d L=-\Omega(d q / d L)-(1-\mu) \lambda-\left(1-\rho_{k}\right) L^{w} R_{L L},
\end{aligned}
$$

where $\Omega=\left(1-\rho_{k}\right) L^{w} R_{L q}-\mu\left[L^{k}\left(e_{q}^{w}-\rho e_{q}^{k}\right)+L^{w} e_{q}^{w}\left(1-\rho_{k}\right)\right]$.

The new effect that is present in this case is the effect of changes in the prices of non-traded good on income and consumption. While for both groups an increase in the price of non-traded good makes the consumption of this good more expensive and thus it exerts a negative impact on their utility, the effect on income is different. Actually, equations (9) and (10) show that the gain or the loss of one group is exactly equal to the loss or the gain of the other group, and thus social welfare is not affected by changes in non-traded goods prices. The effect of migration on the welfare of the two groups is generally ambiguous.

Totally differentiating equation (3'), (7) and (8), treading $\mathrm{L}^{\mathrm{k}} \mathrm{du}^{\mathrm{k}}, \mathrm{L}^{\mathrm{w}} \mathrm{du}^{\mathrm{w}}$, and $\mathrm{dq}$ as the endogenous variables, gives the effect of migration on the price of the nontraded good as:

$$
\Delta(d q / d L)=\left(e_{q}^{w}-R_{q L}\right)-\lambda e_{q u}^{k}+\left(e_{q u}^{w}-e_{q u}^{k}\right)\left[-\lambda \mu+\left(1-\rho_{k}\right) L^{w} R_{L L}\right]
$$

where $\Delta=-Z_{q q}-\left(e_{q u}^{k}-e_{q u}^{w}\right)\left[L^{w} e_{q}^{w}-\left(1-\rho_{k}\right) L^{w} R_{L q}-\rho_{k} \mu R_{q}\right]$, and is positive invoking Walrasian stability in the non-traded good market, and $Z_{q q}=L^{k} e_{q q}^{k}+L^{w} e_{q q}^{w}-R_{q q}$. The first right hand side term in equation (11) shows the effect of migration on the price of

\footnotetext{
${ }^{9}$ From now on, we assume for simplicity that only one non-traded good exists.
} 
the non-traded good through its effect of the excess demand for this good, and is generally ambiguous, in part depending on the factor intensity of this good. ${ }^{10}$ The second and third term shows the effect of migration on the price of the non-traded good through its effect on total income and demand for non-traded good and is generally ambiguous. In the special case where the marginal propensity to consume the non-traded good by workers is equal or greater than the marginal propensity to consume the same good by capitalists (i.e., $e_{q u}^{w} \geq e_{q u}^{k}$ ), and the term $\mathrm{R}_{\mathrm{Lq}}-e_{q}^{w}$ is positive, then immigration reduces the price of the non-traded good (i.e., (dq/dL) is negative).

In the special case where the consumption of the non-traded good by a representative worker and a representative capitalist are equal (i.e., $e_{q}^{w}=e_{q}^{k}=e_{q}$ ), then equation (9) becomes $L^{w} d u^{w} / d L=\left\{\left(1-\rho_{k}\right) L^{w}\left(R_{L q}-e_{q}\right)\right\}(d q / d L)-\mu \lambda+\left(1-\rho_{k}\right) L^{w} R_{L L}$. Thus, in the case where $e_{q}^{w}=e_{q}^{k}=e_{q}, \mathrm{R}_{\mathrm{Lq}}>\mathrm{e}_{\mathrm{q}}$, and $e_{q u}^{w} \geq e_{q u}^{k}$, then immigration reduces the welfare of the workers already in the country.

\section{Social Welfare, Non-traded Goods and Capital Mobility}

In this section we examine the welfare effects of migration when a non-traded good exists and capital is perfectly mobile internationally. In this case the expenditure functions include utility and the price of the non-traded good, and the revenue function includes the price of the non-traded good, labor and capital. Differentiating equation (1), (2), (3) and (8), treading $\mathrm{L}^{\mathrm{k}} \mathrm{du}^{\mathrm{k}}, \mathrm{L}^{\mathrm{w}} \mathrm{du}^{\mathrm{w}}, \mathrm{dK}$ and $\mathrm{dq}$ as the endogenous variables, gives the effect of migration on social welfare as follows:

$$
Z_{q q}^{-1} \widetilde{R}_{K K}^{-1} \Delta_{1}(d W / d L)=-\lambda-\rho_{k} R_{K} \widetilde{R}_{K K}^{-1}\left[R_{K L}+R_{K q} Z_{q q}^{-1}\left(-e_{q}^{w}+R_{q L}\right)\right]
$$

where $\Delta_{1}=\widetilde{R}_{K K} Z_{q q}+\rho_{k} R_{K} R_{K q}-\left(e_{q u}^{k}-e_{q u}^{w}\right)\left\{\left[L^{w} e_{q}^{w}-\left(1-\rho_{k}\right) L^{w} R_{L q}-\rho_{k} \mu R_{q}\right] R_{K K}+\right.$ $\left.\left.\left(1-\rho_{k}\right) L^{w} R_{L K}+\rho_{k} \mu R_{K}\right] R_{K q}\right\}$, and $\widetilde{R}_{K K}=R_{K K}+R_{K q} Z_{q q}^{-1} R_{q K}$ which is negative. $\Delta_{1}$ is positive invoking Walrasian stability in the non-traded good market.

10 Since it is assumed for simplicity that there is a single non-traded good, we can say that it is labor (non-labor) intensive in production if $R_{q L}>0(<0)$. 
The first term on the right hand side of equation (12) is negative and is the net fiscal effect that we have seen previously in the absence of capital mobility. The second term is present due to the fact that capital is internationally mobile and its sign is ambiguous. Through this second term, migration affects the return to capital, and thus welfare, directly, and indirectly through its effect on the price of the non-traded good. The direct effect is positive since it is assumed that $\mathrm{R}_{\mathrm{KL}}$ is positive, while the indirect effect is generally ambiguous. If the non-traded good is relatively capital intensive (i.e., $\mathrm{R}_{\mathrm{Kq}}>0$, and $\mathrm{R}_{\mathrm{Lq}}<0$ ), then this indirect effect is positive and reinforce the direct effect. If the non-traded good is relatively labor intensive (i.e., $\mathrm{R}_{\mathrm{Kq}}<0$, and $\mathrm{R}_{\mathrm{Lq}}>0$ ), and $e_{q}^{w}>R_{q L}$ then again this indirect effect is positive. If, however, $e_{q}^{w}<R_{q L}$, then this indirect effect is negative and it could outweigh the direct effect.

Proposition 4. In the presence of income taxes, transfers, non-traded goods and international capital mobility, marginal immigration reduces the welfare of those already in the country if $\mathrm{R}_{\mathrm{Lq}}>0$, (i.e., $\left.\quad R_{K q}<0\right), \quad e_{q}^{w} \prec R_{q L} \quad$ and $R_{K L} \prec R_{K q} Z_{q q}^{-1}\left(-e_{q}^{w}+R_{q L}\right)$ (sufficient but not necessary conditions).

Since most non-traded goods are services, we expect the non-traded goods to be relatively labor intensive. If in addition the non-traded goods are on average luxury goods, and thus their consumption by a representative worker is relatively small and strongly labor intensive (i.e., $\mathrm{R}_{\mathrm{qL}}$ is high), then we expect marginal immigration to reduce the welfare of those already in the country.

\section{Concluding Remarks}

We build a general equilibrium model of international migration of a small source or host country, producing many traded and non-traded goods, using capital, labor and other factors of production. Two classes of individuals exist in the source or host country. Workers, who possess only labor, and capitalists, who possess labor, capital and other factors of production. Individuals in each class are identical and migrants are from the group of workers. Migration is permanent in the sense that immigrants do not remit any of their income earnings in the host country to the source country. Each country imposes income taxes on wage and non wage income and 
redistributes the tax receipts equally to all individuals in the country. Capital is perfectly mobile internationally.

Within this framework, the paper shows that in the absence of capital mobility, marginal immigration hurts people already in the host country. These results hold whether or not non-traded goods exist in the country. In the presence of international capital mobility, however, the above results are weaker and it could be reversed.

In the absence of non-traded goods and capital mobility, marginal immigration hurts workers already in the country and marginal emigration benefits the initial group of workers in the source country. The presence of international capital mobility decreases the loses of marginal immigration on workers already in the country and decreases the benefits of marginal emigration on the initial group of workers in the source country and it may reverse the original effects. The effect of marginal migration on capitalists in the source or host country is generally ambiguous. 


\section{References}

Berry, R. Albert and Ronald Soligo, 1969, Some Welfare Aspects of International Migration, Journal of Political Economy 77, 778-794.

Djajic, Slobodan, 1998, Emigration and welfare in an economy with foreign capital. Journal of Development Economics 56, 433-445.

Quibria, M.G., 1988, On generalizing the economic analysis of international migration: a note, Canadian Journal of Economics 21, 874-876.

Razin, Assaf and Efraim Sadka, 1995, Resisting migration: Wage rigidity and income distribution, American Economic Review, Papers and Proceedings 85, 312-316.

Rivera-Batiz, F., 1982, International migration, non-traded goods and economic welfare $n$ the source country. Journal of Development Economics 11, 81-90.

Wildasin, E. David, 1994. Income redistribution and migration. Canadian Journal of Economics 27, 637-656

Wellisch, Dietmar and David E. Wildasin, 1996. Decentralized income redistribution and immigration. European Economic Review 40, 187-217.

Wellisch, Dietmar and Uwe Walz, 1998. Why do rich countries prefer free trade over free migration? The role of the modern welfare state. European Economic Review 42, 1595-1612.

Wong, K-Y, 1985, The economic analysis of international migration: a generalization, Canadian Journal of Economics 18, 357-362. 


\section{CESifo Working Paper Series}

(for full list see www.cesifo.de)

712 Thorvaldur Gylfason and Gylfi Zoega, Inequality and Economic Growth: Do Natural Resources Matter?, April 2002

713 Wolfgang Leininger, Contests over Public Goods: Evolutionary Stability and the FreeRider Problem, April 2002

714 Ernst Fehr and Armin Falk, Psychological Foundations of Incentives, April 2002

715 Giorgio Brunello, Maria Laura Parisi, and Daniela Sonedda, Labor Taxes and Wages: Evidence from Italy, May 2002

716 Marta Aloi and Huw Dixon, Entry Dynamics, Capacity Utilisation and Productivity in a Dynamic Open Economy, May 2002

717 Paolo M. Panteghini, Asymmetric Taxation under Incremental and Sequential Investment, May 2002

718 Ben J. Heijdra, Christian Keuschnigg, and Wilhelm Kohler, Eastern Enlargement of the EU: Jobs, Investment and Welfare in Present Member Countries, May 2002

719 Tapio Palokangas, The Political Economy of Collective Bargaining, May 2002

720 Gilles Saint-Paul, Some Evolutionary Foundations for Price Level Rigidity, May 2002

721 Giorgio Brunello and Daniela Sonedda, Labor Tax Progressivity, Wage Determination, and the Relative Wage Effect, May 2002

722 Eric van Damme, The Dutch UMTS-Auction, May 2002

723 Paolo M. Panteghini, Endogenous Timing and the Taxation of Discrete Investment Choices, May 2002

724 Achim Wambach, Collusion in Beauty Contests, May 2002

725 Dominique Demougin and Claude Fluet, Preponderance of Evidence, May 2002

726 Gilles Saint-Paul, Growth Effects of Non Proprietary Innovation, May 2002

727 Subir Bose, Gerhard O. Orosel, and Lise Vesterlund, Optimal Pricing and Endogenous Herding, May 2002

728 Erik Leertouwer and Jakob de Haan, How to Use Indicators for 'Corporatism' in Empirical Applications, May 2002

729 Matthias Wrede, Small States, Large Unitary States and Federations, May 2002 
730 Christian Schultz, Transparency and Tacit Collusion in a Differentiated Market, May 2002

731 Volker Grossmann, Income Inequality, Voting Over the Size of Public Consumption, and Growth, May 2002

732 Yu-Fu Chen and Michael Funke, Working Time and Employment under Uncertainty, May 2002

733 Kjell Erik Lommerud, Odd Rune Straume, and Lars Sørgard, Downstream Merger with Oligopolistic Input Suppliers, May 2002

734 Saku Aura, Does the Balance of Power Within a Family Matter? The Case of the Retirement Equity Act, May 2002

735 Sandro Brusco and Fausto Panunzi, Reallocation of Corporate Resources and Managerial Incentives in Internal Capital Markets, May 2002

736 Stefan Napel and Mika Widgrén, Strategic Power Revisited, May 2002

737 Martin W. Cripps, Godfrey Keller, and Sven Rady, Strategic Experimentation: The Case of Poisson Bandits, May 2002

738 Pierre André Chiappori and Bernard Salanié, Testing Contract Theory: A Survey of Some Recent Work, June 2002

739 Robert J. Gary-Bobo and Sophie Larribeau, A Structural Econometric Model of Price Discrimination in the Mortgage Lending Industry, June 2002

740 Laurent Linnemer, When Backward Integration by a Dominant Firm Improves Welfare, June 2002

741 Gebhard Kirchgässner and Friedrich Schneider, On the Political Economy of Environmental Policy, June 2002

742 Christian Keuschnigg and Soren Bo Nielsen, Start-ups, Venture Capitalits, and the Capital Gains Tax, June 2002

743 Robert Fenge, Silke Uebelmesser, and Martin Werding, Second-best Properties of Implicit Social Security Taxes: Theory and Evidence, June 2002

744 Wendell Fleming and Jerome Stein, Stochastic Optimal Control, International Finance and Debt, June 2002

745 Gene M. Grossman, The Distribution of Talent and the Pattern and Consequences of International Trade, June 2002

746 Oleksiy Ivaschenko, Growth and Inequality: Evidence from Transitional Economies, June 2002 
747 Burkhard Heer, Should Unemployment Benefits be Related to Previous Earnings?, July 2002

748 Bas van Aarle, Giovanni Di Bartolomeo, Jacob Engwerda, and Joseph Plasmans, Staying Together or Breaking Apart: Policy-makers' Endogenous Coalitions Formation in the European Economic and Monetary Union, July 2002

749 Hans Gersbach, Democratic Mechanisms: Double Majority Rules and Flexible Agenda Costs, July 2002

750 Bruno S. Frey and Stephan Meier, Pro-Social Behavior, Reciprocity or Both?, July 2002

751 Jonas Agell and Helge Bennmarker, Wage Policy and Endogenous Wage Rigidity: A Representative View From the Inside, July 2002

752 Edward Castronova, On Virtual Economies, July 2002

753 Rebecca M. Blank, U.S. Welfare Reform: What's Relevant for Europe?, July 2002

754 Ruslan Lukach and Joseph Plasmans, Measuring Knowledge Spillovers Using Patent Citations: Evidence from the Belgian Firm's Data, July 2002

755 Aaron Tornell and Frank Westermann, Boom-Bust Cycles in Middle Income Countries: Facts and Explanation, July 2002

756 Jan K. Brueckner, Internalization of Airport Congestion: A Network Analysis, July 2002

757 Lawrence M. Kahn, The Impact of Wage-Setting Institutions on the Incidence of Public Employment in the OECD: 1960-98, July 2002

758 Sijbren Cnossen, Tax Policy in the European Union, August 2002

759 Chandima Mendis, External Shocks and Banking Crises in Developing Countries: Does the Exchange Rate Regime Matter?, August 2002

760 Bruno S. Frey and Lars P. Feld, Deterrence and Morale in Taxation: An Empirical Analysis, August 2002

761 Lars Calmfors and Åsa Johansson, Nominal Wage Flexibility, Wage Indexation and Monetary Union, August 2002

762 Alexander R. W. Robson and Stergios Skaperdas, Costly Enforcement of Property Rights and the Coase Theorem, August 2002

763 Horst Raff, Preferential Trade Agreements and Tax Competition for Foreign Direct Investment, August 2002

764 Alex Cukierman and V. Anton Muscatelli, Do Central Banks have Precautionary Demands for Expansions and for Price Stability? - Theory and Evidence, August 2002

765 Giovanni Peri, Knowledge Flows and Knowledge Externalities, August 2002 
766 Daniel Friedman and Nirvikar Singh, Equilibrium Vengeance, August 2002

767 Sam Bucovetsky and Michael Smart, The Efficiency Consequences of Local Revenue Equalization: Tax Competition and Tax Distortions, August 2002

768 Tapio Palokangas, International Labour Market Regulation and Economic Growth with Creative Destruction, August 2002

769 Rudi Dornbusch, The New International Architecture, September 2002

770 Hans-Werner Sinn, Weber's Law and the Biological Evolution of Risk Preferences: The Selective Dominance of the Logarithmic Utility Function, September 2002

771 Thomas Mayer, The Macroeconomic Loss Function: A Critical Note, September 2002

772 Seppo Honkapohja and Kaushik Mitra, Learning Stability in Economies with Heterogenous Agents, September 2002

773 David Laidler, Inflation Targets Versus International Monetary Integration - A Canadian Perspective, September 2002

774 Morten I. Lau, Panu Poutvaara, and Andreas Wagener, The Dynamic Cost of the Draft, September 2002

775 Steven Brakman, Harry Garretsen, and Charles van Marrewijk, Locational Competition and Agglomeration: The Role of Government Spending, September 2002

776 Anke S. Kessler and Christoph Lülfesmann, The Theory of Human Capital Revisited: On the Interaction of General and Specific Investments, September 2002

777 Kjell Erik Lommerud, Frode Meland and Lars Sørgard, Unionized Oligopoly, Trade Liberalization and Location Choice, September 2002

778 Antonio Merlo and François Ortalo-Magné, Bargaining over Residential Real Estate: Evidence from England, September 2002

$779 \mathrm{Yu}-\mathrm{Fu}$ Chen and Michael Funke, Exchange Rate Uncertainty and Labour Market Adjustment under Fixed and Flexible Exchange Rates, September 2002

780 Michael S. Michael, International Migration, Income Taxes and Transfers: A Welfare Analysis, September 2002 